\title{
Raptor Research
}

\section{ИЗУЧЕНИЕ ПЕРНАТЫХ ХИЩНИКОВ}

\author{
The Diet of the Osprey Breeding in "Chyrvony Bor" Nature \\ Sanctuary, Belarus
}

\section{ПИТАНИЕ СКОПЫ, ГНЕЗДЯЩЕЙСЯ В ЗАКАЗНИКЕ «КРАСНЫЙ БОР», БЕЛАРУСЬ}

\author{
Kitel D.A. (Working group on raptors and owls, NGO APB-Birdlife-Belarus, Minsk, Belarus) \\ Pljuta M.V. (Ichthyology laboratory, The Scientific and Practical Center for the National \\ Academy of Sciences of Belarus for biological resources, Minsk, Belarus) \\ Kazakova A. V. (Biological department, Belarus State University, Minsk, Belarus)
}

Китель Д.А. (Рабочая группа по соколообразным и совообразным, общественная организация «Ахова птушак Бацькаўшчыны», Минск, Беларусь)

Плюта М.В. (Лаборатория ихтиологии, Научно-практический центр национальной академии наук Беларуси по биоресурсам, Минск, Беларусь) Казакова А.В. (Биологический факультет, Белорусский государственный университет, Минск, Беларусь)

Контакт:

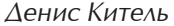

Обшественная организация «Ахова птушак Бацькаўшчыны» 220114 Беларусь Минск

ул. Парниковая, 11 kitelden@gmail.com

\section{Михаил Плюта} Ааборатория ихтиологии,

Научно-практический центр национальной акалемии наук

Беларуси по

биоресурсам 220072 Беларусь

Минск

ул. Акацемическая, 27 micle58@mail.ru

Анастасия Казакова Биологический факультет,

Белорусский государственный университет 220030 Беларусь Минск

ул. Курчатова, 10 nastyucha13733@mail.ru

\section{Резюме}

В статье приводятся данные о питании одной пары скоп (Pandion haliaetus) с севера Беларуси, зафиксированной с помошью онлайн-камеры в 2018 г. В частности, анализируется 231 экземпляр рыб минимум 10 видов. Установлено, что большая часть Аоставляемой к гнезду рыбы не выходит из размерного диапазона 20-30 см. В течение $\Delta н я$

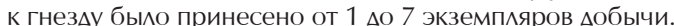

КАючевые слова: пернатые хишники, хишные птицы, скопа, Pandion haliaetus, рыба, питание, онлайн-трансмяция, север Беларуси.

Поступияа в реАакцию: 24.01.2021 г. Принята к публикации: 28.03.2021 г.

Abstract

The article contains data on the diet of Osprey (Pandion haliaetus) breeding at northern Belarus recorded by an online camera in 2018. In particular, 231 individuals of not less than 10 species of fish were analyzed. The average length of the prey fish lays between 20 and $30 \mathrm{~cm}$. From 1 to 7 fishes have been brought to the nest daily.

Keywords: raptors, birds of prey, Osprey, Pandion haliaetus, fish, diet, food composition, webcam surveillance, northern Belarus.

Received: 24/01/2021. Accepted: 28/03/2021.

DOI: $10.19074 / 1814-8654-2021-42-5-8$

\section{Введение}

Питание скопы (Pandion haliaetus) на территории Беларуси изучено слабо. В частности, есть упоминание о плотве (Rutilus rutilus) в желудке птенца, мобытого на территории Березинского заповедника (ФеАюшин, Аолбик, 1967). В.В. Ивановским (2012) в периол с 1976 по 1985 гг. были определены останки 106 экземпляров добычи скопы, собранные в ^отке гнёзд и по присахами. Ввиду мефрицита материала на данную тему мы решили опубликовать Аанные о питании пары скоп, гнездяшейся в республиканском мандшафртном заказнике «Красный бор», которые были записаны видеокамерой во время онлайн-трансляции в 2018 г.

\section{Introduction}

The diet of Osprey (Pandion haliaetus) in Belarus is poorly studied. We found only 2 publications on the subject (Fedyushin, Dolbik, 1967; Ivanovsky, 2012). To shorten this gap, here we publish data on the diet of a pair of Ospreys that inhabited the National Nature Sanctuary "Chyrvony Bor". Data was collected during online broadcast from the active nest of the pair in 2018.

\section{Methods}

The Osprey's nest under study is located on a territory of a bog in the National Nature Sanctuary "Chyrvony Bor" in the Rasony District of the Vitebsk Region. Surroundings of 
Contact:

Denis Kitel

NGO APB-Birdlife-Bela-

rus, chairman

220114 Belarus Minsk

Parnikovaya str., 11

kitelden@gmail.com

Mikhail Pljuta

Ichthyology laboratory,

The Scientific and

Practical Center for the

National Academy of

Sciences of Belarus for

biological resources

220072 Belarus Minsk

Akademicheskaya str., 27

micle58@mail.ru

Anastasia Kazakova Biological department of Belarus state university 220030 Belarus Minsk

Kurchatova str., 10 nastyucha13733@mail.ru

\section{Материал и методика}

Гнездо скопы, за которым велось наблюдение, расположено на верховом болоте Большой Mox в Россонском районе Витебской области на территории республиканского мандшафртного заказника «Красный бор». В 5-километровом рахиусе от гнезда имеется 7 озёр (Глубокое, Шипок, Коморка, Томсино, Среднее Моховое, Большое Моховое, безымянное) обшей плошадью более 101 га, а также реки Ниша и Черепятица суммарной протяжённостью 24 км. Нам неизвестно, каким водным системам отлаёт предпочтение Аанная пара скоп, мы также не исключаем, что самец мог летать за добычей Аальше, чем 5 км.

Видеокамера была закреплена на гнездо 06.04.2018 г., а пол Аеревом и ряном расположена установка автономного питания (солнечная панель, аккумулятор и пр.). Происходяшие на гнезде события трансмировались онлайн через сайт Ivideon ${ }^{3}$. Настройка камеры не позволяла делать запись на сервер всех событий на гнезде, запись начиналась при наличии $в$ вижения в кахре. Ввиду Аанных настроек мы не можем говорить о том, что собранные нами материалы по питанию яв^яются 100\% отражением мействительной картины. В ряде случаев камера включалась с задержкой. Ряд ракурсов также не позволял провести илентифрикацию принесённой добычи. Тем не менее, мы считаем, что результаты приближены к максимально правдоподобной картине.

Весь отснятый материал был внимательно просмотрен, сцены с приносом корма разбиты на калры м^я удобства последуюшего определения вина жертв (рис. 1). Зная размеры гнезда и объектов в поле камеры, мы попытались ранжировать приносимую добычу по размерам.

Приносы рыбы на гнезАо фриксировались Ао 20.06.2018 г. По причине гибели самки и впоследствии выводка нам удалось охватить мишь часть гнездового сезона пары скоп. Хронология событий на этом гнезде уже была опубликована (Китель, Казакова, 2018).

Составленный список видов рыб, АОбытых скопой, не может быть использован $и я я$ описания ихтиофауны заказника «Красный бор», так как мы не знаем точно, гле каждая особь была добыта. Весьма вероятно, что скопа охотилась также в России на территории Себежского национального парка, примыкаюшего вплотную к заказнику, или же летала за педелы границ обеих особо охраняемых природных территорий (ООПТ). the nest in $5 \mathrm{~km}$ radius encompasses 7 lakes with a total area of more than $101 \mathrm{ha}$, and 2 rivers with a total length of $24 \mathrm{~km}$. We do not really know where exactly ospreys from this pair are foraging - on lakes or rivers. We also suppose that the male could take foraging flights longer than $5 \mathrm{~km}$.

A Webcam was fixed at the nest on April 6, 2018. A live view was broadcast via Ivideon ${ }^{3}$. A video stream recording to the server (archiving) was automatically started by the motion detection in the frame. In some cases, archiving began with a short time lag. There were also cases when the angle of view prevented us from prey species identification. However, we consider the number of missing cases is quite low.

Recordings were thoroughly checked for the scenes of prey provisioning. Such scenes were divided by frames for prey species identification (fig. 1). Knowing the size of the nest and some objects in view we could size the prey fish.

On June 13, the female was seen on the nest for the last time. Offspring also died in two days. Prey provisioning was recorded until 20.06.2018. The chronology of events on this nest was published earlier (Kitel, Kazakova, 2018).

\section{Results}

We recorded 231 cases of prey provisioning. We managed to identify 193 specimens of fish up to species and 18 - up to genus. 20 specimens remain unidentified. A total of 10 species were observed (table 1).

A dominating species in the diet of the pair was Bream (Abramis brama) $(n=88$, $38.10 \%$ ), in a lower number Roach (Rutilus rutilus) ( $n=37,16.02 \%)$ and Tench (Tinca tinca) $(n=24,10.39 \%)$ were presented. Together these three species make $64.51 \%$ of the total number of prey items. Pike (Esox lucius) $(n=4)$ was recorded early in the spring only, on 9-11 of April which coincides with a spawning period when pikes gather in warm shallow water and become an easy prey.

Most of the prey items were delivered to the nest already partly eaten. Thus, we managed to estimate the size of only 93 specimens $(40.26 \%$ of the total). We have divided fish into 4 size classes (fig. 2). Most commonly we observed fish $20-30 \mathrm{~cm}$ long $(n=49,15.26 \%)$. The same data is given by the Darwin State Nature Reserve in Russia (Babushkin, Kuznetsov, 2012) and by 


\section{Результаты и их обсуждение}

За периол проведения онлайн-трансляции улалось зафриксировать 231 принос корма на гнезьо. Определить $\Delta о$ вила уда^ось 193 особи рыб 10 виАОв, Ао семейства - 18, остались неопределёнными 20 особей. Полный список жертв скопы и их количество приведены в таблице 1.

Видом-АОминантом в питании изучаемых скоп является ^еш (Abramis brama) $(n=88$, $38,10 \%)$, чуть меньше представлены плотва (Rutilus rutilus) ( $n=37,16,02 \%)$ и минь (Tinca tinca) ( $n=24,10,39 \%)$. Суммарно эти три вина составляют 64,51\% от обшего числа Аобычи скопы. Шука (Esox lucius) в мобыче $(n=4)$ зафриксирована только ранней весной 9-11 апреля, как раз в периол нереста, когла рыба выходит на прогретое мелководье и становится лёгкой добычей.

Так как большинство Аобытых рыб приносились в гнезАо уже частично съедеными, нам удалось определить размер только Аля 93 особей $(40,26 \%$ от обшего количества жертв). Нами были вылелены 4 раз-

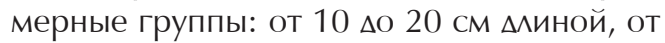
$20 \Delta$ о 30 см, от $30 \Delta$ о 40 см и от $40 \Delta$ О 50 см (рис. 2). Пограничные показатели 20, 30 и 40 смешались в меньшую сторону.

Чаше всего в гнезАо доставлялась рыба $\Delta$ миной от $20 \Delta$ О 30 см $(n=49,15,26 \%$ от всей Аобычи). Такие же ханные мемонстрируют работы по питанию скопы в Аарвинском заповеднике в России (Бабушкин, Кузнецов, 2012) и Аатвии (Kalvans, Bajinskis, 2016). Так, в России на основе анализа 346 особей рыб, пойманных скопой, средняя миина Аобычи составила 27,94 см, в Аатвии - 27,8 см.

В течение $\Delta$ ня самец с Аобычей появлялся на гнезде от $1 \Delta$ о 7 раз (рис. 3). Чаше всего (21 Аень) он приноси^ 3 особи рыб,

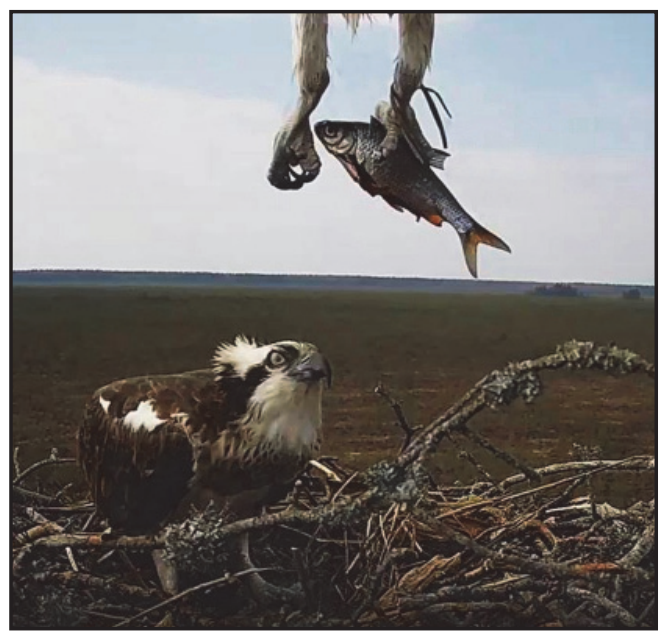

Рис. 1. Самец скопы (Pandion haliaetus) приносит самке плотву (Rutilus rutilus).

Fig. 1. The male Osprey (Pandion haliaetus) brings the roach (Rutilus rutilus) to the female.

researchers from Latvia (Kalvans, Bajinskis, 2016).

The frequency of prey provisioning by the male varies from 1 to 7 times per day (fig. 3). Most often he delivered three fish per day (21 days in total). For 15 days he delivered 2 fish per day, and for 12 days - only one fish per day.

At the end of the unsuccessful breeding, we visited the nest to survey the area below the nest and nearest perches. Besides few scales belonged to several fish specimens we found nothing. We conclude that without video recording it is impossible to analyze osprey's diet. Modern technology let us study the ecology of the species deeper without disturbing it.
Табл. 1. Список $\triangle O-$ бытых скопой (Pandion haliaetus) рыб и их количество.

Table 1. Summary of prey items.

\begin{tabular}{|c|c|c|c|}
\hline & Вим/Species & Количество / Number & $\Delta$ оля, $\% /$ Share, $\%$ \\
\hline \multicolumn{2}{|r|}{ Отрян Шукообразные (Esociformes) } & 4 & 1.73 \\
\hline & Шука / Pike (Esox lucius) & 4 & 1.73 \\
\hline \multicolumn{2}{|r|}{ Отрян Окунеобразные (Perciformes) } & 9 & 3.90 \\
\hline 2 & Окунь речной / Perch (Perca fluviatilis) & 9 & 3.90 \\
\hline \multicolumn{2}{|r|}{ Отрян Карпообразные (Cypriniformes) } & 198 & 85.71 \\
\hline 3 & Аеш / Bream (Abramis brama) & 88 & 38.10 \\
\hline 4 & Плотва / Roach (Rutilus rutilus) & 37 & 16.02 \\
\hline 5 & Аинь / Tench (Tinca tinca) & 24 & 10.39 \\
\hline 6 & Язь / Ide (Leuciscus idus) & 13 & 5.63 \\
\hline 7 & Карась золотой / Crucian carp (Carassius carassius) & 10 & 4.33 \\
\hline 8 & Густера / White Bream (Blicca bjoerkna) & 5 & 2.16 \\
\hline 9 & Карась серебрянный / Goldfish (Carassius auratus) & 2 & 0.87 \\
\hline \multirow[t]{2}{*}{10} & Уклейка / Common Bleak (Alburnus alburnus) & 1 & 0.43 \\
\hline & Карповые sp. (Cyprynidae sp.) & 18 & 7.79 \\
\hline \multicolumn{2}{|r|}{ Рыба sp. (Osteichthyes sp.) } & 20 & 8.66 \\
\hline \multicolumn{2}{|c|}{ Итого / Total: } & 231 & 100 \\
\hline
\end{tabular}




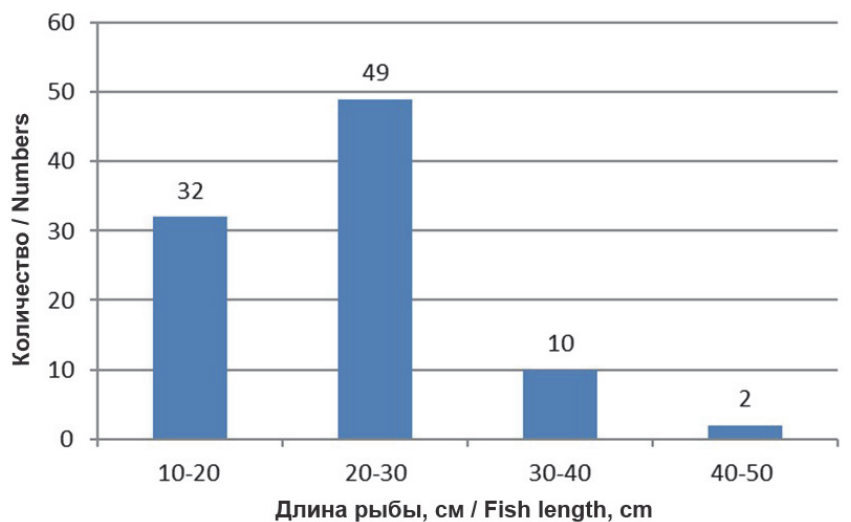

Рис. 2. Количество рыб из разных размерных групп $(\mathrm{n}=93)$.

Fig. 2. Prey items divided by size $(\mathrm{n}=93)$.

Рис. 3. Графиик ежеАневного приноса корма в гнезАо скопами.

Fig. 3. Number of prey items delivered to the nest daily. терсервис» в рамках проекта «Эфрорективная охрана хишных птиц и сов охотничьего хозяйства «Красный бор».

\section{Аитература}

Бабушкин М.В., Кузнецов А.В. Питание скопы в $\triangle$ арвинском заповеднике (северо-западная Россия). - Хишные птицы в Аинамической среде третьего тысячелетия: состояние и перспективы. Труды VI межАународной конореренции по соколообразным и совам Северной Евразии, г. Кривой Рог, Украина, 27-30 сентября 2012 г. Кривой Рог, 2012. С. 330-334. [Babushkin M.V., Kuznetsov A.V. Diet of the Osprey in the Darwin Nature Reserve (North-Western Russia). - Birds of Prey in the Dynamic Envitonment of the Third Millenium: Status and Prospect. Proceedings of the $6^{\text {th }}$ International Conference on Birds of Prey and Owls of North Eurasia, Kryvyi Rih, 27-30 September 2012. Kryvyi Rih, 2012: 330-334. (in Russian).] URL: http://rrrcn. ru/wp-content/uploads/2014/05/38babuchkin.pdf Аата обрашения: 20.01.2021.

Ивановский В.В. Хишные птицы Белорусского Поозерья. Витебск: УО «ВГУ им. П.М. Машерова», 2012. 209 с. [lvanovsky V.V. Birds of prey of the Belarusian Lake District. Vitebsk, 2012: 1-209. (in Russian).] URL: https://lib.vsu.by/xmlui/handle/123456789/13775 Аата обрашения: 20.01.2021.

Китель $\triangle$. .А.,Казакова А.В. Внутривидовые отношения, экология и хронология размножения, питание и сезонные перемешения скоп, обитаюших на Севере Беларуси. - Пернатые хишники и их охрана. 2018. Спецвып. 1. С. 166-168. [Kitel D.A., Kazakova A.V. Intraspeciefic Relationship, Ecology and Chronology of the Breeding, Food Composition and Seasonal Movement of Ospreys from Northern Belarus. - Raptors Conservation. 2018. Suppl. 1: 166-168.] URL: http://rrrcn.ru/ru/ archives/32677 Аата обрашения: 20.01.2021.

Фелюшин А.В., Аолбик М.С. Птицы Белоруссии. Минск. 1967. 520 с. [Fedyushin A.V., Dolbik M.S. Birds of Belarus. Minsk. 1967: 1-520. (in Russian).] URL: http://ashipunov.me/ shipunov/school/books/fedjushin1967_pritsy_ belorussii.djvu Аата обрашения: 20.01.2021.

Kalvans A., Bajinskis J. The diet composition of breeding Ospreys (Pandion haliaetus) in Latvia. Environmental and Experimental Biology. 2016. 14: 107-111. DOI: 10.22364/eeb.14.15 URL: http://eeb.lu.Iv/EEB/201610/EEB_XIV_Kalvans.pdf Аата обрашения: 20.01.2021.
Установка веб-камеры и её обслуживание было профринансировано ООО «Ин-

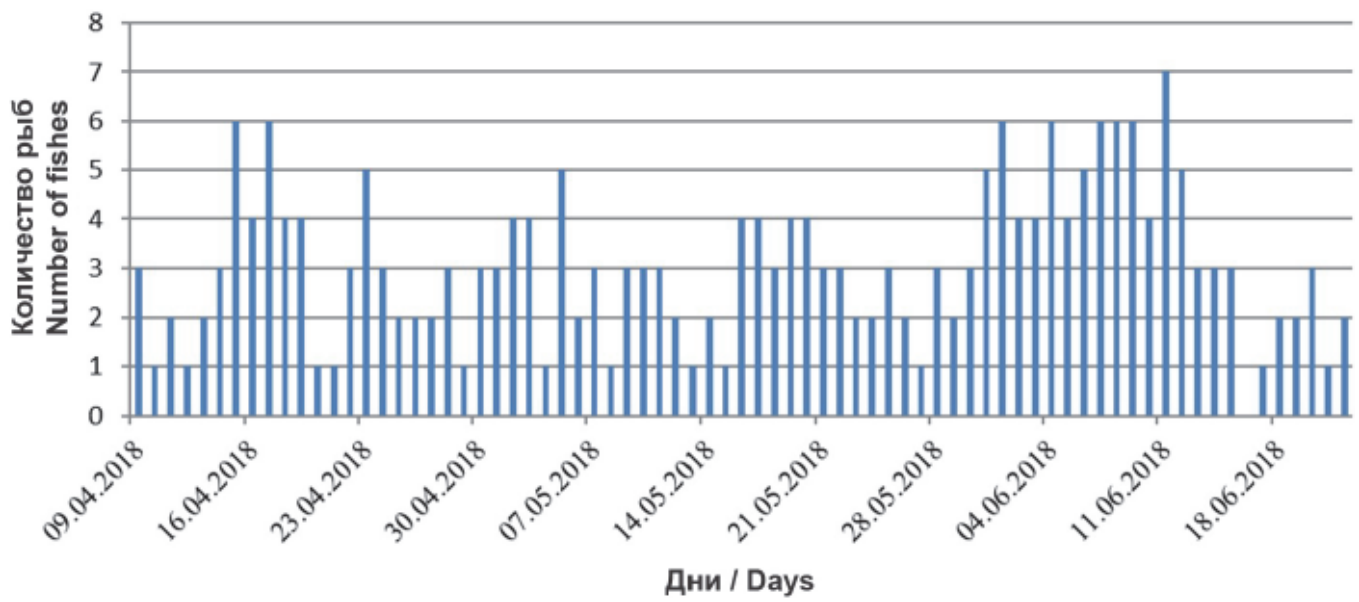

